\title{
ANALISIS KOMPONEN MAKNA KATA BERMAKNA 'MELIHAT' DALAM BAHASA INDONESIA DAN BAHASA JAWA (ANALISIS KONTRASTIF)
}

\author{
Kingkin Puput Kinanti ${ }^{1}$, Endang Setiyo Astuti ${ }^{2}$ \\ ${ }^{1,2}$ IKIP Budi Utomo, Jalan Citandui 41 Malang \\ Fakultas Ilmu Sosial dan Humiora \\ Surel:kinantipuput8@gmail.com
}

\begin{abstract}
Abstrak
Penelitian ini merupakan penelitian semantik analisis komponen makna. Penelitian bertujuan untuk mengetahui perbedaan makna kata 'melihat' bahasa Indonesia dengan bahasa Jawa. Data yang diguakan adalah leksikon kata 'melihat'. Data dikumpulkan dari leksikonleksikon yang bermakna 'melihat' dalam KBBI untuk leksikon bahasa Indonesia dan Kamus Jawa Bausastra Jawa untuk leksikon bahasa Jawa. Analisis menggunakan analisis kontrastif. Hasil penelitian menunjukkan bahwa bahasa Indonesia dan bahasa Jawa memiliki beragam leksikon yang bermakna 'melihat' yaitu 16 leksikon dalam bahasa Indonesia dan pada bahasa Jawa terdapat 19 leksikon. Leksikon bermakna 'melihat' dalam bI adalah memandang, menengok, menatap, menengadah, menilik, menonton, mengerling, melirik, mengamati, memperhatikan, melotot, mengintip, menyaksikan, mengincar, meninjau, dan mengintai dan dalam bJ adalah ndeleng, nginguk, mergoki, ndingkik, nginceng, nyimak, nglirik, nonton, nginjen, nyawang, ngamati, ngawasi, mirsani, ngulati, namatake, mentheleng, mriksa, dan niti. Dari analisis komponen makna ternyata satu konsep kata yang bermakna 'melihat' ditemukan lebih banyak persamaan dibandingkan dengan perbedaannya. Perbedaan hanya terdapat pada komponen tingkat tutur yang tidak dimiliki oleh bahasa Indonesia
\end{abstract}

Kata kunci: komponen makna, melihat, bahasa Indonesia, bahasa Jawa, semantik.

\begin{abstract}
This research is a semantic research of meaning component analysis. This study aims to determine the difference in the meaning of the word 'see' in Indonesian and in Javanese. The data used is the lexicon of the word 'see'. Data were collected from lexicon which means 'to see' in the KBBI for the Indonesian language lexicon and the Javanese Bausastra Javanese Dictionary for the Javanese language lexicon. Analysis using contrastive analysis. The results showed that Indonesian and Javanese have various lexicons which mean 'to see', namely 16 lexicon in Indonesian and 19 lexicon in Javanese. The lexicon meaning 'to see' in bI is to look, look, stare, look up, glance, watch, glance, glance, observe, pay attention, stare, peek, witness, aim, review, and spy and in bJ are ndeleng, snore, catch, ndingkik, nginceng, listening, nglirik, watching, nginjen, nyawang, observing, observing, mirsani, ngulati, namatake, mentheleng, mriksa, and niti. From the analysis of the components of meaning, it turns out that one word concept which means 'to see' is found to have more similarities than differences. The difference is only in the speech level component which is not owned by Indonesian.
\end{abstract}

Keyword: lexicon, view, semantics, meaning component analysis

\section{A. PENDAHULUAN}

Kata bermakna 'melihat' dalam bahasa Indonesia dan bahasa Jawa memiliki beragam variasi. Kata 'melihat' secara umum dijelaskan sebagai hal mengetahui sesuatu 
melalui indra mata. Dalam hal ini, melihat tidak hanya berkaitan dengan membuka mata serta menunjukkan objek tertentu. Akan tetapi, melihat adalah membuka mata untuk mengetahui objek yang menjadi sasaran.

Kata 'melihat' dalam bahasa Indonesia dan bahasa Jawa memiliki beberapa hiponim. Dalam bahasa Indonesia kata melihat berhiponim dengan kata memandang, menengok, menatap, menengadah, menilik, menonton, mengkerling, melirik, mengamati, memperhatikan, melotot, mengintip, menyaksikan, dan mengincar. Kata melihat dalam bahasa Jawa adalah ndelok yang berhiponim dengan kata ndeleng, nginguk, mergoki, ndingkik, nginceng, nyimak, nglirik, nonton, nginjen, nyawang, ngamati, ngawasi, mirsani, ngulati, namatake, mentheleng, mriksa, dan niti.

Beberapa hiponim dari kata yang bermakna 'melihat' dalam bahasa Indonesia dan bahasa Jawa ditemukan di dalam kamus. Ada banyaknya hiponim dari kata melihat terkadang sangat menyulitkan bagi orang yang bukan merupakan penutur asli bahasa Jawa dan bahasa Indonesia. Kesalahan pemakaian kata dapat menimbulkan perbedaan makna meskipun antar kata yang digunakan tersebut masih memiliki hubungan. Atas dasar itulah, analisis terhadap komponen makna sangat dibutuhkan untuk mengetahui komponen pembeda dari masing-masing kata.

Penelitian komponen makna telah beberapa kali dilakukan. Larasati menulis judul tesis "Kajian Semantis: Leksem-leksem yang mengandung Makna 'membawa' dalam Bahasa Indonesia”, Muniah, Dad dkk pada tahun 2000 meneliti hiponim dengan judul "Kehiponiman Dalam Bahasa Indonesia" yang diterbitkan oleh Pusat Bahasa Departemen Pendidikan Nasional. Penelitian berjudul lain mengenai analisis komponen makna adalah penelitian berjudul "Analisis Komponen Makna Kata yang Bermakna Dasar Memukul dalam Bahasa Madura Dialek Pamekasan oleh Elvan Efendi. Penelitian ini berbeda karena menggunakan data bahasa Madura. Penelitian berjudul "Dimensi dan Komponan Makna Medan Leksikal Verba Bahasa Indonesia yang Berciri (+Tindakan + Kepala+ Manusia) oleh Bakdal Ginanjar, D.Edi Subroto dan Sumarlam. Penelitian lain berjudul “Tipe Semantis Komponen Makna Nomina Bahasa Indonesia dalam Antologi Cerpen Jakaeta Kafe Karya Tatyana oleh Renny Septiani.

Penelitian ini akan mendeskripsikan tentang analisis komponen makna pembeda kata yang bermakna “melihat' dalam bahasa Indonesia dan bahasa Jawa. Analisis 
komponen makna pembeda kata bermakna 'melihat' dalam bahasa Indonesia dan bahasa Jawa belum pernah dilakukan sebelumnya. Tujuan penelitian ini adalah untuk mengetahui komponen-komponen pembeda yang terdapat dalam kata yang bermakna 'melihat' dalam bahasa Indonesia dan bahasa Jawa. Metode yang digunakan adalah metode analisis komponen makna dan analisis kontrastif.

Dengan menggunakan analisis kontrastif, maka dapat diketahui persamaan dan perbedaan komponen-komponen makna kata yang bermakna 'melihat' dalam bahasa Jawa dan bahasa Indonesia. Metode analisis komponen makna menganalisis leksikon berdasarkan komponen diagnostik. Analisis seperti itu adalah proses pencirian makna leksikon atas komponen makna diagnostiknya, yaitu komponen yang menimbulkan kontras antara leksikon yang satu dan yang lain di dalam satu medan leksikal. Komponen makna bersama adalah ciri yang tersebar dalam semua leksikon yang menjadi dasar makna bersama, terutama dalam satu perangkat leksikal (Lyons, 1981).

\section{B. KAJIAN TEORI}

Analisis komponen makna adalah salah satu analisis yang digunakan dalam studi semantik. Semantik merupakan ilmu yang mempelajari tentang makna. Makna adalah pertautan yang ada di antara unsur-unsur bahasa itu sendiri terutama kata-kata. Makna menurut Palmer (1976) hanya menyangkut intra bahasa. Sejalan dengan pendapat tersebut, Lyons (1977:204) menyebutkan bahwa mengkaji atau memberikan makna suatu kata ialah memahami kajian kata tersebut yang berkenaan dengan hubungan-hubungan makna yang membuat kata tersebut berbeda dari kata-kata lain. Kata-kata memiliki hubungan yang disebut dengan medan makna. Untuk mengetahui hubungan dari kata-kata harus diketahui komponen maknanya. Analisis komponen makna dilakukan terhadap kata-kata dengan menguraikannya sampai komponen makna yang sekecil-kecilnya (Pateda, 2010:261).

Komponen makna suatu kata diuraikan dengan makna yang terkandung di dalam kata itu sendiri, tetapi ada kalanya berubah karena konteks yang mendukungnya. Dengan demikian, dapat terjadi sebuah kata yang sama dapat mempunyai jumlah komponen makna yang berbeda. Komponen makna itu terdiri atas komponen makna bersama, komponen makna pembeda, dan komponen makna tambahan (Lyons, 1981). 
Komponen makna bersama adalah satuan terkecil yang dimiliki bersama beberapa kata. Komponen makna ini tidak dapat digunakan untuk membedakan makna. Sedangkan komponen makna pembeda ialah satuan makna terkecil yang dapat digunakan untuk membedakan makna. Komponen makna tambahan ialah satuan makna terkecil yang tidak selalu dikandung suatu kata, sifatnya hanya sebagai tambahan keterangan (Lyons, 1981).

\section{METODE PENELITIAN}

Penelitian ini adalah penelitian berjenis deskriptif kualitatif. Pengumpulan data dilakukan dengan menggunakan teknik pustaka. Data dikumpulkan dengan melakukan pengumpulan leksikon-leksikon yang bermakna 'melihat' dalam KBBI edisi ketiga untuk leksikon bahasa Indonesia dan Kamus Jawa Bausastra Jawa edisi kedua untuk leksikon bahasa Jawa.

Data yang telah dikumpulkan kemudian dianalisis dengan menggunakan analisis kontrastif dan deskriptif komparatif. Analisis deksriptif dilakukan setelah data terkumpul kemudian diidentifikasi kata-kata yang bermakna 'melihat' dalam bahasa Indonesia dan bahasa Jawa. Kata-kata tersebut kemudian dicatat pada tabel kemudian dilanjutkan dengan klasifikasi data. Tahapan analisis data meliputi a) mengumpulkan semua kata yang bermakna 'melihat' dalam bahasa Indonesia dan bahasa Jawa, b) meletakkan kata-kata tersebut dalam tabel kemudian membandingkan setiap komponen makna kata pada masing-masing bahasa, c) menyimpulkan komponen pembeda dari masing-masing kata dalam dua bahasa tersebut, d) membandingkan analisis komponen pembeda dari dua bahasa yang dianalisis.

\section{HASIL DAN PEMBAHASAN}

\section{Analisis Komponen Makna Kata Bermakna 'melihat' dalam bahasa Indonesia}

Melihat merupakan aktivitas membuka mata untuk mengenali atau mengetahui objek tertentu. Kata 'melihat' termasuk pada jenis kata kerja. Dalam bahasa Indonesia kata 'melihat' memiliki 16 hiponim, yaitu: memandang, menengok, menatap, menengadah, menilik, menonton, mengerling, melirik, mengamati, memperhatikan, melotot, mengintip, menyaksikan, mengincar, meninjau, dan mengintai . 
Analisis komponen makna kata bermakna 'melihat' dalam bahasa Indonesia dapat dianalisis dengan menggunakan analisis komponen makna. Kata bermakna 'melihat' dapat dianalisis dengan menetapkan komponen pembedanya. Komponen pembeda kata bermakna 'melihat' adalah cara, objek, waktu, jarak, dan arah.

Berikut ini hasil analisis komponen makna kata bermakna 'melihat dapat dilihat pada tabel berikut.

Tabel 1. Analisis komponen kata bermakna melihat dalam bahasa Indonesia

\begin{tabular}{|c|c|c|c|c|c|c|c|c|c|c|c|c|c|c|}
\hline \multirow{3}{*}{$\begin{array}{l}\mathrm{N} \\
\mathrm{o} .\end{array}$} & \multirow[t]{3}{*}{ LEKSEM } & \multicolumn{13}{|c|}{ KOMPONEN PEMBEDA } \\
\hline & & \multicolumn{3}{|c|}{ Cara } & \multicolumn{2}{|c|}{ Objek } & \multicolumn{3}{|c|}{ Waktu } & \multicolumn{3}{|c|}{ Jarak } & \multicolumn{2}{|c|}{ Arah } \\
\hline & & $\begin{array}{l}\text { Mata } \\
\text { terbuka } \\
\text { normal }\end{array}$ & $\begin{array}{l}\text { Mata } \\
\text { terbuka } \\
\text { lebar }\end{array}$ & $\begin{array}{l}\text { Mata } \\
\text { terbuka } \\
\text { sempit }\end{array}$ & $\begin{array}{l}\text { Benda } \\
\text { mati }\end{array}$ & $\begin{array}{l}\text { Benda } \\
\text { hidup }\end{array}$ & Sekilas & $\begin{array}{l}\text { Agak } \\
\text { lama }\end{array}$ & lama & Dekat & $\begin{array}{l}\text { Agak } \\
\text { jauh }\end{array}$ & Jauh & tetap & $\begin{array}{l}\text { beru } \\
\text { bah }\end{array}$ \\
\hline 1 & Memandang & + & - & - & + & + & - & + & - & + & - & - & + & - \\
\hline 2 & Menengok & + & - & - & + & + & + & - & - & + & - & - & - & + \\
\hline 3 & Menatap & + & - & - & + & + & - & - & + & + & - & - & + & - \\
\hline 4 & Menengadah & + & - & - & + & + & + & - & - & - & + & - & - & + \\
\hline 5 & Menilik & + & - & - & + & + & - & - & + & + & - & - & + & - \\
\hline 6 & Menonton & + & - & - & + & + & - & - & + & + & - & - & + & - \\
\hline 7 & Mengerling & - & - & + & - & + & + & - & - & + & - & - & + & - \\
\hline 8 & Melirik & - & - & + & + & + & + & - & - & + & - & - & - & + \\
\hline 9 & Mengamati & + & - & - & + & + & - & - & + & + & - & - & + & - \\
\hline 10 & Memperhatikan & + & - & - & + & + & - & - & + & + & - & - & + & - \\
\hline 11 & Melotot & - & + & - & - & + & + & - & - & + & - & - & + & - \\
\hline 12 & Mengintip & - & - & + & - & + & - & + & - & - & + & - & + & - \\
\hline 13 & Menyaksikan & + & - & - & + & + & - & - & + & + & - & - & + & - \\
\hline 14 & Mengincar & + & - & - & - & + & - & - & + & - & + & - & + & - \\
\hline 15 & Meninjau & + & - & - & + & - & - & + & - & - & - & + & - & + \\
\hline 16 & Mengintai & + & - & - & - & + & - & - & + & - & - & + & + & - \\
\hline
\end{tabular}

Berdasarkan hasil analisis komponen makna pembeda di atas, dapat dianalisis bahwa leksem-leksem dari data di atas, memiliki beberapa unsur pembeda yaitu:

a. Komponen pembeda cara

Komponen pembeda cara berkaitan dengan cara mata melihat objek. Cara mata dapat dibedakan menjadi tiga macam, yaitu mata terbuka normal, mata terbuka lebar, dan mata terbuka sempit. Dari hasil analisis di atas, dapat dilihat bahwa komponen mata terbuka normal terdapat pada beberapa leksem, yaitu leksem memandang, menengok, menatap, menengadah, menilik, menonton, mengamati, memperhatikan, menyaksikan, mengincar, meninjau dan mengintai. Komponen mata terbuka lebar terdapat pada leksem melotot dan komponen mata terbuka sempit terdapat pada leksem mengerling, melirik, dan mengintip. 
b. Komponen pembeda objek

Komponen pembeda objek berkaitan dengan objek yang dilihat oleh mata, yaitu objek benda mati dan objek benda hidup. Objek benda mati berkaitan dengan benda-benda yang tidak bergerak, misalnya buku, meja, televisi, gedung, dan lain sebagainya, sedangkan benda hidup adalah manusia dan hewan. Dari hasil analisis komponen makna di atas, dapat dilihat bahwa objek benda mati dan benda hidup merupakan objek yang dilihat pada leksem memandang, menengok, menatap, menengadah, menilik, mengamati, memperhatikan, melirik, dan menyaksikan. Komponen objek benda hidup adalah komponen yang terdapat pada leksem mengkerling, melotot, mengintip, mengincar dan mengintai. Komponen benda mati terdapat pada leksem meninjau.

c. Komponen pembeda waktu

Komponen makna pembeda waktu berkaitan dengan lama aktivitas melihat itu dilakukan, yaitu sekilas, agak lama, atau lama. Komponen makna waktu sekilas terdapat pada leksem menengok, menengadah, mengerling, melotot dan melirik. Komponen makna pembeda waktu agak lama terdapat pada leksem memandang, mengintip, dan meninjau. Komponen makna pembeda waktu lama terdapat pada leksem menatap, menonton, mengamati, memperhatikan, dan menyaksikan, menilik, mengincar, dan mengintai.

d. Komponen pembeda jarak

Komponen pembeda jarak dapat dibagi menjadi 3 yaitu jarak dekat, agak jauh dan jarak jauh. Jarak dekat berkaitan terdapat pada leksem memandang, menengok, menatap, menilik, mengerling, melirik, mengamati, memperhatikan, melotot, dan menyaksikan. Komponen agak jauh terdapat pada leksem menengadah, mengintip, dan mengincar. Sedangkan komponen jauh terdapat pada leksem meninjau dan mengintai.

e. Komponen pembeda arah

Komponen pembeda arah berkaitan dengan arah mata ketika melakukan aktivitas melihat, yaitu dengan arah tetap atau arah yang berubah. Komponen 
arah tetap berkaitan dengan leksem memandang, menatap, menilik, menonton, mengerling, mengamati, memperhatikan, melotot, mengintip, menyaksikan, mengintai dan mengincar. Arah yang berubah terdapat pada leksem menengok yaitu berubah arah ke samping kanan atau kiri, menengadah yaitu arah ke atas, melirik yaitu arah mata berubah ke samping kanan atau samping kiri dan meninjau yaitu melihat ke arah bawah.

Kamus Bahasa Indonesia mendefinisikan kata melihat sebagai ihwal mengetahui sesuatu melalui indera mata. Jadi, kata itu tidak hanya menyatakan ihwal membuka mata serta menunjukkannya ke objek tertentu, tetapi juga ihwal mengetahui objek itu. Hiponim kata melihat adalah memandang yang memiliki makna menyatakan perbuatan membuka mata dengan normal untuk mengetahui objek berupa benda mati atau benda hidup (misalnya pemandangan atau manusia) dalam waktu yang agak lama, objek dekat dan dengan arah yang tetap. Pemakaian kata memandang yang ditekankan adalah adanya objek yang menarik. Selanjutnya kata menatap adalah membuka mata dengan normal untuk mengetahui objek yang berupa benda mati atau benda hidup. Perbuatan itu dilakukan dalam waktu yang relatif lama dan pelaku merasa perlu mendekat ke objek dengan arah yang tetap.

Menengok merupakan perbuatan untuk mengetahui objek berupa benda mati atau benda hidup dengan mata terbuka normal, hanya sekilas saja dilakukan, objek dekat dan arah berubah. Menengadah memiliki makna melihat ke arah atas untuk mengetahui objek benda mati atau benda hidup yang dilakukan hanya sekilas dan berjarak agak jauh. Menilik bermakna melihat dengan sungguh-sungguh, mata terbuka normal untuk mengetahui objek benda mati atau benda hidup arah tetap, jarak dekat dan dilakukan dalam waktu yang lama.

Kata menonton menyatakan perbuatan melihat objek karena didorong oleh rasa ingin tahu akan apa yang terjadi. Perbuatan ini dilakukan dengan mata terbuka normal untuk mengetahui benda mati atau benda hidup (pertunjukan, televisi, peristiwa yang terjadi pada manusia) dalam waktu yang lama, dekat dengan objek dan arah mata tetap. Mengkerling bermakna melihat dengan mata yang yang terbuka sempit ke sebelah kanan atau kiri, sekilas saja dilakukan dalam jarak yang dekat. Perbuatan ini dilakukan pada objek berupa benda hidup (manusia). Melirik bermakna melihat ke sebelah dengan 
tajam dengan mata yang terbuka sempit untuk melihat objek berupa benda mati atau benda hidup dan sekilas dilakukan. Kata mengamati (atau mengamat-amati) menyatakan perbuatan memperhatikan objek berupa benda mati atau hidup dengan teliti, relatif lama, dekat, dan arah yang tetap. Memperhatikan bermakna melihat dengan sungguh-sungguh suatu objek yang berupa benda mati atau benda hidup dengan mata terbuka normal, jarak dekat dan arah yang tetap.

Melotot bermakna melihat dengan melebarkan mata untuk mengetahui objek berupa manusia, tidak dilakukan dalam waktu yang lama, jarak dekat dan arah yang tetap. Mengintip bermakna melihat dengan mata yang yang terbuka sempit dan terdapat penghalang untuk mengetahui objek berupa benda hidup, secara sembunyi-sembunyi dalam jarak yang agak jauh dan waktu yang agak lama serta arah yang tetap. Kata menyaksikan menyatakan perbuatan melihat sesuatu untuk mengetahui kebenarannya dengan mata terbuka normal untuk mengetahui objek yang berupa benda mati atau benda hidup dalam waktu yang relatif lama, jarak yang dekat dan arah yang tetap. Mengincar bermakna melihat dengan memincingkan sebelah mata (dengan maksud jahat), dengan mata terbuka normal untuk melihat objek hidup (manusia). Perbuatan ini dilakukan dalam waktu yang relatif lama, jarak yang jauh dan arah yang tetap. Kata meninjau menyatakan perbuatan melihat dari tempat yang tinggi dengan mata terbuka lebar dalam waktu yang relatif lama, jarak yang jauh. Kata mengintai bermakna melihat dengan sembunyi-sembunyi (bermaksud hendak mengetahui gerak-gerik orang), dalam waktu yang relatif lama, jarak yang jauh dan arah yang tetap.

\section{Analisis Komponen Makna Kata Bermakna 'melihat' dalam bahasa Jawa}

Kata yang bermakna 'melihat' dalam bahasa Jawa adalah kata ndelok. Kata ndelok memiliki beberapa hiponim, yaitu ndeleng, nginguk, mergoki, ndingkik, nginceng, nyimak, nglirik, nonton, nginjen, nyawang, ngamati, ngawasi, mirsani, ngulati, namatake, mentheleng, mriksa, dan niti.

Dalam Kamus Bahasa Jawa Bausastra Jawa, ndelok memiliki definisi 'melihat'. Hiponim ndelok adalah ndeleng 'melihat', nginguk 'menjenguk', mergoki 'melihat tidak sengaja', ndingkik 'mengintai', nginceng 'mengintai, memandang lurus sebelah mata', nyimak 'menyimak, nglirik 'melirik', nonton 'menonton', nginjen 'mengintai, nyawang 
'menatap', ngamati 'memperhatikan', ngawasi 'mengawasi', mirsani 'melihat', ngulati 'mengawasi', namatake 'melihat dengan detail dan seluruhnya', mentheleng 'melihat dengan mata lebar', mriksa 'memeriksa', mendelik 'melebarkan mata karena marah', niti 'meneliti'.

Dari data di atas, dapat dilihat bahwa kata bermakna 'melihat' dalam bahasa Jawa memiliki jumlah hiponim lebih banyak dari bahasa Indonesia. Hasil analisis komponen kata bermakna melihat dapat dilihat pada Tabel 2.

Tabel 2 Analisis komponen pembeda kata bermakna melihat dalam bahasa Jawa

\begin{tabular}{|c|c|c|c|c|c|c|c|c|c|c|c|c|c|c|c|c|}
\hline \multirow[t]{3}{*}{ No } & \multirow[t]{3}{*}{ LEKSEM } & \multicolumn{13}{|c|}{ KOMPONEN PEMBEDA } & & \\
\hline & & \multicolumn{3}{|c|}{ Cara } & \multicolumn{2}{|c|}{ Objek } & \multicolumn{3}{|c|}{ Waktu } & \multicolumn{3}{|c|}{ Jarak } & \multicolumn{2}{|c|}{ Arah } & \multicolumn{2}{|c|}{ Tingkat tutur } \\
\hline & & $\begin{array}{l}\text { Mata } \\
\text { terbuka } \\
\text { normal }\end{array}$ & $\begin{array}{l}\text { Mata } \\
\text { terbuka } \\
\text { lebar }\end{array}$ & $\begin{array}{l}\text { Mata } \\
\text { terbuka } \\
\text { sempit }\end{array}$ & $\begin{array}{l}\text { Benda } \\
\text { mati }\end{array}$ & $\begin{array}{l}\text { Benda } \\
\text { hidup }\end{array}$ & sekilas & $\begin{array}{l}\text { Agak } \\
\text { lama }\end{array}$ & lama & dekat & $\begin{array}{l}\text { Aga } \\
\mathrm{k} \\
\text { jauh }\end{array}$ & jauh & $\begin{array}{l}\text { teta } \\
\mathrm{p}\end{array}$ & $\begin{array}{l}\text { Berub } \\
\text { ah }\end{array}$ & $\begin{array}{l}\text { kra } \\
\text { ma }\end{array}$ & $\begin{array}{l}\text { ngok } \\
\text { o }\end{array}$ \\
\hline 1 & Ndelok & + & - & - & + & + & - & - & + & + & - & - & + & - & - & + \\
\hline 2 & Ndeleng & + & - & - & + & + & - & - & + & + & - & - & + & - & - & + \\
\hline 3 & Nginguk & + & - & - & + & + & - & + & - & + & - & - & - & + & - & + \\
\hline 4 & Mergoki & + & - & - & - & + & + & - & - & + & - & - & + & - & - & + \\
\hline 6 & Nginceng & - & - & + & - & + & - & + & - & - & + & - & + & - & - & + \\
\hline 7 & Nyimak & + & - & - & + & + & - & - & + & + & - & - & + & - & - & + \\
\hline 8 & Nglirik & - & - & + & - & + & + & - & - & + & - & - & - & + & - & + \\
\hline 9 & Nonton & + & - & - & + & + & - & - & + & + & - & - & + & - & - & + \\
\hline 10 & Nyawang & + & - & - & - & + & - & + & - & + & - & - & + & - & - & + \\
\hline 11 & Ngamati & + & - & - & + & + & - & - & + & + & - & - & + & - & - & + \\
\hline 12 & Ngawasi & + & - & - & - & + & - & - & + & - & + & - & + & - & - & + \\
\hline 13 & Mirsani & + & - & - & + & + & - & - & + & + & - & - & + & - & + & - \\
\hline 14 & Ngulati & + & - & - & - & + & - & - & + & - & - & + & + & - & - & + \\
\hline 15 & Namatake & + & - & - & + & + & - & - & + & + & - & - & + & - & - & + \\
\hline 16 & Mentheleng & - & + & - & + & + & - & - & + & - & + & - & + & - & - & + \\
\hline 17 & Mriksa & + & - & - & + & + & - & + & - & + & - & - & + & - & - & + \\
\hline 18 & Mendelik & - & + & - & - & + & + & - & - & + & - & - & + & - & - & + \\
\hline 19 & Niti & + & - & - & + & + & - & - & + & + & - & - & + & - & - & + \\
\hline
\end{tabular}

Berdasarkan hasil analisis komponen makna pembeda di atas, dapat dianalisis bahwa leksem-leksem dari data di atas, memiliki beberapa unsur pembeda yaitu:

a. Komponen pembeda cara

Komponen pembeda cara berkaitan dengan cara mata melihat objek. Cara mata dapat dibedakan menjadi tiga macam, yaitu mata terbuka normal, mata terbuka lebar, dan mata terbuka sempit. Dari hasil analisis di atas, dapat dilihat bahwa komponen mata terbuka normal terdapat pada beberapa leksem, yaitu leksem ndelok, ndeleng, nginguk, mergoki, nyimak, nonton, nyawang, ngamati, ngawasi, mirsani, ngulati, namateke, mriksa, dan niti. Komponen mata terbuka 
lebar terdapat pada leksem mentheleng dan mendelik, dan komponen mata terbuka sempit terdapat pada leksem nginceng dan nglirik.

b. Komponen pembeda objek

Komponen pembeda objek berkaitan dengan objek yang dilihat oleh mata, yaitu objek benda mati dan objek benda hidup. Komponen pembeda benda mati dan benda hidup terdapat pada leksem ndelok, ndeleng, nginguk, nyimak, nonton, ngamati, mirsani, namatake, mentheleng, mriksa, dan niti. Komponen makna pembeda objek benda hidup yang menjadi sasaran aktivitas melihat terdapat pada leksem mergoki, nginceng, nyawang, ngawasi, ngulati, dan mendelik.

c. Komponen pembeda waktu

Komponen makna pembeda waktu berkaitan dengan lama aktivitas melihat itu dilakukan, yaitu sekilas, agak lama, atau lama. Komponen makna waktu sekilas terdapat pada kata mergoki, nglirik, dan mendelik. Komponen makna pembeda waktu agak lama terdapat pada leksem nginguk, nginceng, nyawang, dan mriksa. Komponen makna pembeda waktu lama terdapat pada leksem ndelok, ndeleng, nyimak, nonton, ngamati, ngawasi, mirsani, ngulati, namatake, mentheleng, dan niti.

d. Komponen pembeda jarak

Komponen pembeda jarak dapat dibagi menjadi 3 yaitu jarak dekat, agak jauh dan jarak jauh. Jarak dekat berkaitan terdapat pada leksem ndelok, ndeleng, nginguk, mergoki, nyimak, nglirik, nonton, nyawang, ngamati, ngawasi, namatake, mriksa, niti, dan mendelik. Komponen agak jauh terdapat pada leksem nginceng, ngawasi dan mentheleng. Sedangkan komponen jauh terdapat pada leksem ngulati.

e. Komponen pembeda arah

Komponen pembeda arah berkaitan dengan arah mata ketika melakukan aktivitas melihat, yaitu dengan arah tetap atau arah yang berubah. Komponen arah tetap berkaitan dengan leksem ndelok, ndeleng, mergoki, nginceng, nyimak, nonton, nyawang, ngamati, ngawasi, mirsani, ngulati, namatake, mentheleng, 
mriksa, mendelik. Arah yang berubah terdapat pada leksem nginguk dan nglirik yaitu arah mata berubah ke samping kanan atau kiri.

f. Komponen pembeda tingkat tutur

Komponen pembeda tingkat tutur terdapat pada bahasa Jawa karena bahasa Jawa adalah bahasa yang memiliki tingkat tutur, yaitu bahasa krama atau disebut bahasa halus digunakan ketika berbahasa dengan orang yang lebih tua atau dalam ragam resmi sedangkan bahasa ngoko digunakan untuk ragam tidak resmi dan penutur yang seumuran. Dengan demikian, komponen pembeda makna tingkat tutur dapat dijadikan sebagai komponen pembeda. Komponen pembeda tingkat tutur krama terdapat pada leksem mirsani. Sedangkan leksem yang lain yang terdapat pada data di atas adalah leksem pada tingkat tutur ngoko.

Berdasarkan analisis komponen makna yang telah dilakukan, dapat dijelaskan bahwa dalam bahasa Jawa, terdapat leksem yang lebih banyak daripada bahasa Indonesia. Leksem ndelok dan ndeleng merupakan leksem yang bersinonim dan bisa saling menggantikan. Leksem mirsani juga merupakan sinonim dari ndelok dan ndeleng. Hanya saja, pada leksem mirsani merupakan leksem yang digunakan pada tingkat tutur krama. Ketiga leksem ini memiliki komponen makna yang sama unsurunsurnya, yaitu mata terbuka normal,objek yang dilihat berupa benda mati dan benda hidup, dilakukan dalam waktu yang relatif lama dan jarak yang dekat serta arah yang tetap. Nginguk merupakan aktivitas melihat dengan membuka mata normal dengan waktu yang relatif lama, jarak yang dekat dan arah yang tetap. Mergoki merupakan aktivitas mengetahui sesuatu yang disembunyikan, biasanya adalah objek berupa manusia, dalam waktu yang relatif cepat, arah yang tetap.

Leksem nginceng adalah perbuatan melihat dengan mata terbuka sempit dan dilakukan dengan sembunyi-sembunyi terhadap orang yang jaraknya agak jauh dengan arah yang tetap. Leksem nyimak, ngamati dan ngawasi memiliki komponan makna yang sama, yaitu mata terbuka normal, objek berupa benda mati dan benda hidup, dilakukan dalam waktu yang relatif lama, jarak yang dekat dan arah yang tetap.

Nglirik merupakan perbuatan melihat ke arah samping dengan tajam, untuk melihat manusia dengan waktu yang relatif cepat, jarak yang dekat. Nonton merupakan 
perbuatan melihat dengan mata terbuka normal untuk melihat benda mati dan benda hidup dalam waktu yang relatif lama, jarak yang dekat dan arah yang tetap. Nyawang merupakan perbuatan melihat dengan mata normal, untuk melihat objek benda orang dalam waktu yang relatif lama dan arah yang tetap. Ngulati merupakan perbuatan melihat dengan mata normal dalam waktu yang relatif lama jarak yang jauh dan arah yang tetap.

Namatake merupakan perbuatan melihat dengan sungguh-sungguh dan detail. Perbuatan ini dilakukan untuk melihat objek benda mati dan benda hidup dalam waktu yang relatif lama dan arah yang tetap. Mentheleng merupakan perbuatan membuka mata dengan lebar untuk mengetahui objek dalam waktu yang relatif lama dan arah yang tetap. Mriksa merupakan perbuatan melihat dengan mata normal untuk mengetahui apa yang terjadi pada objek benda mati atau benda hidup dengan arah yang tetap. Mendelik merupakan aktivitas membuka mata dengan lebar karena tidak menyukai objek (manusia) dengan waktu yang relatif cepat dalam arah yang tetap. Selanjutnya, yang terakhir adalah niti yaitu aktivitas melihat dengan mata normal untuk mengetahui benda mati dan benda hidup dalam waktu yang lama dan arah yang tetap.

\section{Analisis Kontrastif Komponen Pembeda Kata Bermakna 'melihat' dalam bahasa Indonesia dan bahasa Jawa}

Analisis konstrastif terhadap kata yang bermakna melihat dilakukan setelah melakukan analisis komponen makna terhadap masing-masing bahasa. Berdasarkan analisis yang telah dilakukan, dapat dijelaskan bahwa dalam bahasa Indonesia dan bahasa Jawa perbuatan yang bermakna 'melihat' memiliki beragam leksikon. Pada bahasa Indonesia terdapat 16 leksikon dan pada bahasa Jawa terdapat 19 leksikon. Pada bahasa Jawa memiliki lebih banyak variasi karena bahasa Jawa memiliki ragam tindak tutur. Komponen makna 'melihat' pada kedua bahasa ini pada umumnya sama. Hanya saja terdapat perbedaan pada satu jenis komponen yaitu pada komponen tingkat tutur. 
Tabel 3 Persamaan yang terdapat pada kata bermakna 'melihat' dalam bJ dan bI

\begin{tabular}{|c|c|c|c|}
\hline \multicolumn{2}{|r|}{ Persamaan } & $\mathrm{bI}$ & $\mathrm{bJ}$ \\
\hline \multirow[t]{3}{*}{ cara mata } & Terbuka normal & $\begin{array}{l}\text { memandang, menengok, } \\
\text { menatap, menengadah, } \\
\text { menilik, menonton, } \\
\text { mengamati dan } \\
\text { memperhatikan, } \\
\text { menyaksikan, mengincar, } \\
\text { meninjau dan mengintai. }\end{array}$ & $\begin{array}{l}\text { ndelok, ndeleng, } \\
\text { nginguk, mergoki, } \\
\text { nyimak, nonton, } \\
\text { nyawang, ngamati, } \\
\text { ngawasi, mirsani, } \\
\text { ngulati, namateke, } \\
\text { mriksa, dan niti. }\end{array}$ \\
\hline & Terbuka lebar & melotot & $\begin{array}{l}\text { mentheleng dan } \\
\text { mendelik. }\end{array}$ \\
\hline & mata terbuka sempit & $\begin{array}{l}\text { mengerling, melirik, dan } \\
\text { mengintip }\end{array}$ & nginceng dan nglirik. \\
\hline \multirow[t]{3}{*}{ objek } & sekilas & $\begin{array}{l}\text { menengok, menengadah, } \\
\text { mengerling, melotot dan } \\
\text { melirik }\end{array}$ & $\begin{array}{l}\text { mergoki, nglirik, dan } \\
\text { mendelik }\end{array}$ \\
\hline & Agak lama & $\begin{array}{l}\text { memandang, mengintip, } \\
\text { dan meninjau. }\end{array}$ & $\begin{array}{l}\text { nginguk, nginceng, } \\
\text { nyawang, dan mriksa }\end{array}$ \\
\hline & lama & $\begin{array}{l}\text { menatap, menonton, } \\
\text { mengamati, } \\
\text { memperhatikan, } \\
\text { menyaksikan, menilik, } \\
\text { mengincar, dan mengintai } \\
\text { d }\end{array}$ & \begin{tabular}{lr}
\multicolumn{1}{c}{ ndelok, } & ndeleng, \\
nyimak, & nonton, \\
ngamati, & ngawasi, \\
mirsani, & ngulati, \\
namatake, & mentheleng, \\
dan niti. &
\end{tabular} \\
\hline \multirow[t]{3}{*}{ jarak } & Jarak dekat & $\begin{array}{l}\text { memandang, menengok, } \\
\text { menatap, menilik, } \\
\text { mengerling, melirik, } \\
\text { mengamati, } \\
\text { memperhatikan, melotot, } \\
\text { dan menyaksikan }\end{array}$ & $\begin{array}{l}\text { delok, ndeleng, nginguk, } \\
\text { mergoki, nyimak, } \\
\text { nglirik, nonton, } \\
\text { nyawang, ngamati, } \\
\text { ngawasi, namatake, } \\
\text { mriksa, niti, dan } \\
\text { mendelik. }\end{array}$ \\
\hline & Agak jauh & $\begin{array}{l}\text { menengadah, mengintip, } \\
\text { dan mengincar }\end{array}$ & $\begin{array}{l}\text { ginceng, ngawasi dan } \\
\text { mentheleng }\end{array}$ \\
\hline & jauh & meninjau dan mengintai & ngulati. \\
\hline \multirow[t]{2}{*}{ arah } & arah tetap & $\begin{array}{l}\text { memandang, menatap, } \\
\text { menilik, menonton, } \\
\text { mengerling, mengamati, } \\
\text { memperhatikan, melotot, } \\
\text { mengintip, menyaksikan, } \\
\text { mengintai dan mengincar }\end{array}$ & $\begin{array}{l}\text { delok, ndeleng, mergoki, } \\
\text { nginceng, nyimak, } \\
\text { nonton, nyawang, } \\
\text { ngamati, ngawasi, } \\
\text { mirsani, ngulati, } \\
\text { namatake, mentheleng, } \\
\text { mriksa, mendelik. }\end{array}$ \\
\hline & arah yang berubah. & $\begin{array}{l}\text { menengok, menengadah } \\
\text {, melirik }\end{array}$ & nginguk dan nglirik \\
\hline
\end{tabular}




\section{E. KESIMPULAN}

Penelitian ini menemukan bahwa bahasa Indonesia dan bahasa Jawa memiliki beragam leksikon yang bermakna 'melihat' yaitu 16 leksikon dalam bahasa Indonesia dan pada bahasa Jawa terdapat 19 leksikon. Leksikon bermakna 'melihat' dalam bI adalah memandang, menengok, menatap, menengadah, menilik, menonton, mengerling, melirik, mengamati, memperhatikan, melotot, mengintip, menyaksikan, mengincar, meninjau, dan mengintai dan dalam bJ adalah ndeleng, nginguk, mergoki, ndingkik, nginceng, nyimak, nglirik, nonton, nginjen, nyawang, ngamati, ngawasi, mirsani, ngulati, namatake, mentheleng, mriksa, dan niti. Dari analisis komponen makna ternyata satu konsep kata yang bermakna 'melihat' ditemukan lebih banyak persamaan dibandingkan dengan perbedaannya. Perbedaan hanya terdapat pada komponen tingkat tutur yang tidak dimiliki oleh bahasa Indonesia. Terdapat lebih banyak persamaan tersebut menguntungkan bagi pembelajar bahasa kedua yang mempelajari bahasa Indonesia

\section{F. SARAN}

Penelitian mengenai analisis kontranstif terhadap kata yang bermakna 'melihat' dalam bahasa Indonesia dan bahasa Jawa adalah penelitian awal untuk mengidentifikasi persamaan maupun perbedaan dari leksikon dengan makna kata 'melihat'. Penelitian ini dapat dilakukan penelitian lanjutan yaitu penelitian dengan membandingkan beberapa bahasa selain bahasa Indonesia dan bahasa Jawa, yaitu dengan membandingkan dengan bahasa Inggris atau bahasa asing yang lain. Penelitian lanjutan tersebut tentu dapat menambah khasanah dari ilmu semantik khususnya mengenai analisis komponen makna dan bermanfaat bagi pembelajar bahasa asing.

\section{DAFTAR PUSTAKA}

Chaer, Abdul. 1989. Pengantar Semantik Bahasa Indonesia. Jakarta: Rineka Cipta. Hadiwidjoyo, Purbo. 1993. Kata dan Makna. Bandung: ITB Bandung.

Larasati, P. 2001. Kajian Semantis: Leksem-leksem yang mengandung Makna 'membawa' dalam Bahasa Indonesia. Tesis. Yogyakarta: Universitas Gadjah Mada.

Lyons, John. 1977. Semantics Vol. 1. Cambridge: Cambridge University Press. 
Lyons, John. 1981. Language, Meaning and Context. Cambridge: Cambridge University Press.

Muniah, Dad dkk. 2000. Kehiponiman Dalam Bahasa Indonesia. Jakarta: Pusat Bahasa Departemen Pendidikan Nasional.

Pateda, Mansoer. 2010. Semantik Leksikal. Jakarta: Rineka Cipta.

Palmer. 1976. Semantics. Cambridge: Cambridge University Press.

Tim Peneliti Balai Bahasa dan Fakultas Sastra Universitas Gadjah Mada, 1990. Tipetipe Semantik Verba Bahasa Jawa. Jakarta: Departemam Pendidikan dan Kebudayaan.

Tim Peneliti Balai Bahasa FPBS IKIP SanataDharma. 1986. Tipe-tipe Semantik Adjektiva Bahasa Jawa. Jakarta: Departemam Pendidikan dan Kebudayaan.

Tim Penulis Balai Bahasa Yogyakarta. 2011. Kamus Basa Jawa (Bausastra Jawa). Yogyakarta: Kanisius.

Tim Penyusun Kamus Pusat Bahasa. 2008. Kamus Besar Bahasa Indonesia. Jakarta: Balai Pustaka.

Wedhawati. 1997. "Konfigurasi Medan Leksikal (+Suara+) dalam Bahasa Indonesia". Disertasi. Yogyakarta: Unversitas Gadjah Mada. 